\title{
Using of Barkhausen Noise Analysis and X-Ray Diffraction for Evaluation Of Surface Integrity
}

\author{
Schmidová Lucie ${ }^{1}$, Bakalova Totka ${ }^{1}$, Malec Jiří ${ }^{2}$ \\ ${ }^{1}$ Institute for Nanomaterials, Advanced Technologies and Innovation, Department of the Preparation and Analysis of \\ Nanostructures, Technical University of Liberec, Studentská 2, 46117 Liberec, Czech Republic, lucie.schmidova@tul.cz, \\ totka.bakalova@tul.cz \\ ${ }^{2}$ Department of Analytic Services, PCS s.r.o., Náměstí republiky 63, 591 01Žd’ár nad Sázavou, Czech Republic, \\ j.malec@pcs.cz
}

This paper presents results of study of grinded gears in order to describes surface integrity and verify the correlation between Barkhausen noise analysis and X-ray diffraction. Gears are used in the wind power plant and made of case-hardened steel 18CrNiMo7-6. Barkhausen noise analysis and $\mathrm{X}$-ray diffraction was used for measurement. Barkhausen analysis method is one of the fast nondestructive methods used to assess the integrity of surface. For comparison of grinding processes were used different cutting speeds and numbers of material removal. $X$-ray diffraction method was used also for measurement of residual stresses. Due to correlation between measured values the optimization of grinding process of gears will be done.

Keywords: Barkhausen noise, x-ray diffraction, grinding of gears, surface integrity

\section{Acknowledgement}

This paper is related to the investigation on the Specific University Research Projects which are supported by the Ministry of Education (MSMT) of the Czech Republic.

The paper was supported in part by the Project OP VaVpI Centre for Nanomaterials, Advanced Technologies and Innovation CZ.1.05/2.1.00/01.0005 and by the Project Development of Research Teams of R\&D Projects at the Technical University of Liberec CZ.1.07/2.3.00/30.0024. This paper was supported in part by MPO ČR as part of project MPO TIP FR-TI4/054 - „Increasing the efficiency of spur gearing by optimization of heat, chemical-heat and mechanical treatment".

\section{References}

[1] MALEC, Jiří. Některé příliš neznámé pojmy. Strojírenská technologie, 2006, roč. XI., č. 3, s. 4-5. ISSN 12114162.

[2] HOLEŠOVSKÝ, František. Stanovení zbytkových napětí v povrchu po obrábění. Strojírenská technologie, 2006, roč. XI, č. 3, s. 29-32. ISSN 1211-4162.

[3] OCHODEK, Vladislav. Využití Barkhausenova šumu ke kontrole a optimalizaci procesu broušení. Strojírenská technologie, 2006, roč. XI., č. 3, s. 17-21. ISSN 1211-4162.

[4] GUPTA, H., ZHANG, M., PARAKKA, A. P., Barkhausen effect in ground steels. Acta Materialia, 1997, roč. 45, č. 5, s. 1917-1921, ISSN 1359-6454.

[5] VRKOSLAVOVÁ, Lucie, BAKALOVÁ, Totka. Hodnocení zbytkových napětí metodou analýzy Barkhausenova šumu v porovnání s RTG difrakcí. Jemná mechanika optika, 2013, roč. 58, č. 1, s. 11-13. ISSN 0447-6441.

[6] BUMBÁLEK, Bohumil, MALEC, Jiří. Dokončovací operace a jejich význam pro funkci součástí. Strojírenská technologie, 2006, roč. XI., č. 3, s. 25-28. ISSN 1211-4162.

[7] BUMBÁLEK, L., Zbytková napětí určovaná pomoci Barkhausenova šumu. Strojírenská technologie, 2004, roč. IX, č. 3, s. 11-15, ISSN 1211-4162.

[8] ČUBAN, J., CALONIUS, O., PIETOLA, M., JERSÁK, J. Fatigue life and surface integrity measurements of S355J2 steel used in hydraulic components. Manufacturing Technology. Rec. K. Kocman, I. Mrkvica. Vol. 11, December 2011, č. -. s. 5 - 11. ISSN 1213-2489, ISBN 978-80-7414-415-8. 